\title{
A civil society view of rare disease public policy in six Latin American countries
}

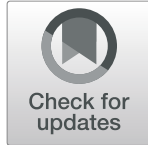

Mo Mayrides ${ }^{1 *}$, Eva Maria Ruiz de Castilla ${ }^{2}$ and Silvina Szelepski ${ }^{3}$

\begin{abstract}
Patients with rare diseases across the world struggle to access timely diagnosis and state-of-the-art treatment and management of their conditions. Several recently published reviews highlight the importance of country efforts to address rare diseases and orphan drugs policy comprehensively. However, many of these reviews lack depth and detail at the local level, which we believe is necessary for rare disease advocates to identify and prioritize opportunities for strengthening each country's policy framework.

We asked leading patient advocates from civil society organizations their views on rare disease public policy in Argentina, Brazil, Chile, Colombia, Mexico, and Peru with a focus on whether specific laws and regulations in these six Latin American countries have been promulgated. From December 2018 to March 2019 we supplemented their perspectives with evidence from accessible literature using key search terms. For each country, we prepared a detailed analysis on how laws or other policy initiatives took shape and the steps taken since to implement them. This allowed us to identify five broad policy categories for subsequent analysis: national laws, national regulations, health system incorporation of rare disease treatments, care delivery, and patient engagement.

By describing the different approaches, challenges and timelines across six countries, our research demonstrates that strengthening rare disease policy first requires a common understanding and local consensus of each country's recent past and current situation. Subsequent analysis based on a set of common policy dimensions led us to where we believe salient opportunities lie for each of these countries to strengthen their overall policy framework for rare disease patients.
\end{abstract}

Keywords: Rare diseases, Orphan drugs, National laws, Policy, Legislation, Regulations, Patient advocacy, Patient engagement, Health system incorporation, Latin America

\section{Background}

Rare diseases are known to often impact patients from the time of birth, affect multiple organ systems, are severely disabling, reduce life expectancy, and impair physical and mental abilities. Due to their low prevalence, unique and coordinated efforts are necessary to address quality of life and prevent significant early mortality and morbidity. Distinct challenges for rare disease patients include early and accurate diagnosis, as well as access to effective treatment. Policy makers, patients and payers struggle with costly treatments and inadequate care coordination and infrastructure. Most medical professionals have very limited knowledge of rare diseases unless they are specialized in certain disease areas [1].

\footnotetext{
* Correspondence: mo.mayrides@emoluva.com

'Emoluva Partners, LLC, 10142 SW 79th Avenue, Miami, FL 33156, USA Full list of author information is available at the end of the article
}

As a result, many more countries worldwide are recognizing the need to address rare diseases and orphan drug policy comprehensively. In a literature review of policies for orphan drug access in 35 countries, researchers found that 27 have orphan drug legislation in place, 18 have national plans, 26 offer incentives for orphan drug research and development, and 33 provide for official reimbursement of orphan drugs [2]. An 11-country analysis of rare disease policies found that most have plans or at least intend to develop national plans to address rare diseases [3]. Researchers found that even those countries without formal national plans had developed some policies to address health care access and/or services for patients with rare diseases.

This review explores rare disease public policy in Argentina, Brazil, Chile, Colombia, Mexico, and Peru. The challenges across Latin America are similar to other

(c) The Author(s). 2020 Open Access This article is distributed under the terms of the Creative Commons Attribution 4.0 International License (http://creativecommons.org/licenses/by/4.0/), which permits unrestricted use, distribution, and 
parts of the world in that patients still struggle to access timely diagnosis and state-of-the-art treatment and management of their conditions. Meanwhile, the regulatory frameworks and legal protections in Latin America are relatively new as decision makers generally lack reliable information and have only recently become more aware of the unique challenges posed by rare diseases [4]. The six countries we studied were also included in a recent rare disease policy global review of the literature with results published in November 2018 [5].

\section{Methodology}

We wanted to take this kind of research to a new level of detail. Specifically, we wanted to know whether specific laws and regulations in these six countries in Latin America had been promulgated and if so, the current environment and focus for policy implementation in each country. Updated and specific information on rare disease policy implementation in each country will help our respective stakeholder communities identify important gaps and address unmet needs.

We gathered information from leading patient advocates for rare disease patients in each of the countries studied via telephone and during the course of face-toface patient advocacy meetings in December 2016, March 2017, July 2017, October 2017, December 2017, and December 2018. It was also important to match the experiences and perspectives that were shared with evidence from accessible literature using key search terms in PubMed Central, Google Scholar, general online searches using Google, reviews of international and local patient advocacy organization websites, public legislative databases, and article searches in academic specialty journals such as the Pan-American Journal of Public Health. Abstracts from literature search results were scanned to determine usefulness and relevance to the research. In a few cases where access to a full publication was limited, we directly contacted authors via email to obtain the studies of interest. This desktop research was conducted from December 2018 through March 2019 and included review of publications and other available resources in either English, Spanish, or Portuguese.

For each country, we prepared a detailed analysis beginning with national laws or rare disease regulations in countries where official laws are not yet on the books. How these laws or initiatives took shape and the steps taken since to implement them allowed us to identify five broad policy categories for subsequent analysis. These five categories are detailed in Table 1. Analysis among the six countries using these categories led us to where we believe the greatest opportunities lie for each of these countries to strengthen their overall policy framework for rare disease patients.
Table 1 Policy Categories for Analysis

\begin{tabular}{ll}
\hline Policy Category & Description \\
\hline National Laws & Existence of a national law specific to rare diseases \\
National & Regulations published (or drafted) by the government \\
Regulations & to implement the national law \\
Health System & Inclusion of rare diseases and treatments in health \\
Incorporation & system financing and reimbursement programs \\
Care Delivery & $\begin{array}{l}\text { Extent to which care models are utilized or proposed, } \\
\text { such as rare disease centers of excellence or reference } \\
\text { centers }\end{array}$ \\
Patient & Level of engagement by governments of patient \\
Engagement & advocates and their organizations \\
\hline
\end{tabular}

\section{National Laws}

Colombia [6], Peru [7], Mexico [8], and Argentina [9] have adopted national laws passed by each's Congress to specifically address rare diseases. These are described in Table 2. In Brazil, the government issued an ordinance in 2014 without national legislation [10], though there are as many as 14 bills pending in Congress to address different elements of rare disease policy [12]. In Chile, the 2015 Ricarte Soto [11] Law had originated with an exclusive focus on rare diseases, but was modified to provide financial protection for the broader category of high-cost diseases [13].

Mexico's law is the least descriptive; the nation revised its general health law in 2012 to define rare diseases based on incidence and to task the Health Secretary with ensuring the problem be addressed by any means. The legislatures in Peru and Argentina passed comprehensive national laws in 2011, but implementation is just beginning in both countries.

Only in Argentina is the national law being codified at the state or municipal level [14], although some cities in Colombia have used that country's 2010 national law as a model for local policy $[15,16]$. Colombia's law is the oldest, while Chile's Ricarte Soto Law the newest; the difference in approach is noteworthy. Colombia's law is a social protection measure with rare disease patients considered a protected class. In Chile, only select rare disease patients are covered, and while financial protection is critical, additional policy elements for the rare disease community have yet to be considered.

There are opportunities in each of the six countries to improve the legal framework for rare disease patients. As discussed, in Chile the gaps in the Ricarte Soto Law present an opportunity for rare disease experts and advocates to argue for a legal framework specifically for rare diseases. In Argentina, Colombia, and Peru, these opportunities are mostly in governments following through with implementation regulations. In Mexico, there has been little in the way of concerted action to address rare diseases since the revision of the health law in 2012. Rare disease advocates in Brazil are advocating 
Table 2 National Laws on Rare Diseases in 6 Latin American Countries

\begin{tabular}{|c|c|c|c|}
\hline Country & Law/Ordinance & Date Enacted & Description \\
\hline Argentina & Law 26,689 & June 29, 2011 & $\begin{array}{l}\text { Defines rare diseases in Argentina as those that affect } 1 \text { of every } 2000 \text { persons and } \\
\text { dictates comprehensive care and coverage for rare disease patients. It mandates } \\
\text { national patient- and disease-specific data registries, centers of excellence, } \\
\text { interdisciplinary care for rare disease patients, expanded newborn screening programs, } \\
\text { and research and development of health technologies to address rare diseases. Of } \\
\text { note, in Argentina rare diseases are referred to in Spanish as "diseases of low } \\
\text { prevalence" given the negative connotation of the word "rare." }\end{array}$ \\
\hline Brazil & Ordinance 199 & January 30, 2014 & $\begin{array}{l}\text { Ordinance } 199 \text { is an administrative act (not passed by Congress). It calls for greater } \\
\text { public awareness, improving diagnosis, increasing education and training among } \\
\text { health professionals, expanding reference centers, and developing clinical protocols } \\
\text { for prioritized rare diseases. Ordinance } 199 \text { expands a } 2009 \text { policy on clinical genetics [10]. }\end{array}$ \\
\hline Chile & Law 20.850 & June 1, 2015 & $\begin{array}{l}\text { The Financial Protection System for High Cost Diagnostics and Treatments (Ricarte } \\
\text { Soto Law) creates a program for diagnostic and treatment coverage for select high-cost } \\
\text { diseases and, as such, facilitates access for some rare disease patients. The law } \\
\text { originated with a focus on rare diseases, but is not specific to rare diseases [11]. }\end{array}$ \\
\hline Colombia & Law 1392 & July 2, 2010 & $\begin{array}{l}\text { Mandates social protection for all with rare diseases and measures to address in a } \\
\text { comprehensive manner the needs of these patients in all dimensions and in all } \\
\text { relevant phases of disease awareness, diagnosis, prevention, treatment, and ongoing } \\
\text { management. The law guarantees access to medicines and diagnosis, calls for health } \\
\text { professional training in rare diseases, a data/information collection system, centers of } \\
\text { excellence, and rare disease research networks [6]. }\end{array}$ \\
\hline Mexico & $\begin{array}{l}\text { Article } 224 \text { bis } \\
\text { and bis } 1 \text { of the } \\
\text { General Health Law }\end{array}$ & January 30, 2012 & $\begin{array}{l}\text { Defines orphan medicines for rare diseases that affect }<5 \text { individuals in } 10,000 \text { and } \\
\text { mandates the nation's Secretary of Health consider any and all means necessary to } \\
\text { make these medicines available to the Mexican population [8]. }\end{array}$ \\
\hline Peru & Law 29698 & June 4, 2011 & $\begin{array}{l}\text { Declares of national interest the prevention, diagnosis, and comprehensive treatment } \\
\text { for persons with rare diseases. Calls on the Ministry of Health to adopt mechanisms to } \\
\text { ensure orphan drugs are available to patients, develop a rare disease patient registry, } \\
\text { build a national action plan, seek measures to improve diagnosis, and include rare } \\
\text { diseases in medical education and training curricula. The law considers rare disease } \\
\text { services and treatments in Peru a priority for annual health budgeting and resource } \\
\text { allocation purposes [7]. }\end{array}$ \\
\hline
\end{tabular}

for Congress to wrap together several legislative proposals into one larger bill, which could be an important mechanism for modernizing that nation's rare diseases administrative ordinance [12].

\section{National Regulations}

Table 3 lists national regulations on rare diseases in the six countries. In Colombia, at least 6 implementing regulations [20-25] have been issued since the national law passed in 2010, although most are related to how the country identifies and officially registers rare diseases and patient caseload nationwide. Only recently is Colombia moving beyond this; in April 2018 the Health Ministry issued its first resolution on the arrangement of clinical care networks for rare disease patients [25]. Brazil's ordinance is heavily focused on specialized care for rare disease patients within the Sistema Único da Saúde (SUS), but implementation has been slowed by the requirement that each rare disease have its own clinical protocol and therapeutic guideline (PCDT) [12]. More recent PCDTs and incorporations of rare disease medicines into SUS should provide new, positive momentum for the outlook in Brazil.

Peru published a final regulation in February 2019 [26], but this version of rulemaking differs from earlier drafts and much remains to be defined as the Ministry of Health begins implementation. The rule lays out what seems to be a substantial bureaucracy for evaluating both new medicines and rare disease patient cases, so it may take significant time before impact can be evaluated. Based on the rule, however, it seems much in Peru will depend on budget impact studies and the availability of funds within the reimbursement structures of the main payer systems, which usually means new barriers to impede instead of expand patient access. Also, beyond reimbursement, there is a chance additional elements of rare disease policy will be addressed more comprehensively when the Ministry develops Peru's national plan, which is one the other mandates in the final regulation.

Argentina has two resolutions and one decree on the books to implement national rare disease policy. One resolution combines rare diseases with congenital abnormalities and establishes a national program within the Health Secretary [17]. The decree on the other hand is focused only on implementing the law for rare diseases, but leaves several sections blank in terms of describing actions to be taken by the government [18]. This regulatory ambiguity may have slowed concerted efforts to address rare diseases comprehensively in Argentina, although a second resolution recently issued constitutes a 
Table 3 National Regulations for Rare Diseases in 6 Latin American Countries

\begin{tabular}{|c|c|c|c|}
\hline Country & Regulation(s) & Date Enacted & Description \\
\hline \multirow[t]{2}{*}{ Argentina } & Resolution 2329 & December 22, 2014 & $\begin{array}{l}\text { Creates national program for rare diseases and congenital anomalies. For rare diseases, } \\
\text { specifies developing a list of these and a national patient registry. All other provisions } \\
\text { such as advisory board, public awareness, training of public health professionals, and a } \\
\text { national network of diagnosis and care centers apply to both rare diseases and } \\
\text { congenital anomalies [17]. }\end{array}$ \\
\hline & Decree 794 & May 11, 2015 & $\begin{array}{l}\text { Specifically regulates the national rare diseases law with provisions such as a national } \\
\text { advisory board, studies to determine the existing care infrastructure, and minimum } \\
\text { coverage standards. Most of the specific mandates in the national law are left } \\
\text { "unregulated" in the decree [18]. }\end{array}$ \\
\hline- & Resolution 271/19 & February 13, 2019 & $\begin{array}{l}\text { Establishes the Advisory Board for Rare Diseases and Congenital Anomalies to be led by } \\
\text { the Ministry of Health and to include representatives from several hospitals, one medical } \\
\text { society, and five patient-based organizations. Mandates the Board create rare diseases list } \\
\text { for Ministry approval [19]. }\end{array}$ \\
\hline Brazil & N/A & - & See Ordinance 199 \\
\hline Chile & N/A & - & See Law 20.850 \\
\hline Colombia & Decree 1954 & September 19, 2012 & Describes the data collection mechanism on number of rare diseases in Colombia [20]. \\
\hline- & Resolution 430 & February 20, 2013 & Lists 1940 different rare diseases in the country [21] \\
\hline- & Resolution 3681 & September 19, 2013 & $\begin{array}{l}\text { Specifies how the government would collect information on rare disease patients via the } \\
\text { high-cost account. Data from the one-time census of patients in } 2013 \text { was made public via } \\
\text { the Ministry's SISPRO system capturing data on just over 13,000 patients, including their } \\
\text { age, gender, type of rare disease, and geographic residence [22] }\end{array}$ \\
\hline- & Resolution 123 & January 21, 2015 & $\begin{array}{l}\text { Mandates the continued reporting of hemophilia and related coagulopathies to the } \\
\text { high-cost account. These were the only diseases mandated for continued reporting beyond } \\
\text { the one-time census of rare disease patients in } 2013 \text { [23] }\end{array}$ \\
\hline- & Resolution 2048 & June 9, 2015 & $\begin{array}{l}\text { Updates the number of rare diseases in Colombia to } 2149 \text { with each assigned a number } \\
\text { code }(1-2149) \text {. The coding is important for use in health system settings with the goal of } \\
\text { improving surveillance of rare diseases over time and nationwide [24] }\end{array}$ \\
\hline- & Resolution 651 & March 1, 2018 & $\begin{array}{l}\text { Outlines the processes, standards, and criteria for health centers to become officially } \\
\text { recognized rare disease reference centers for diagnosis, treatment, and management. Also } \\
\text { defines how these reference centers would then link to each other in networks and } \\
\text { sub-networks to cover all of Colombia [25]. }\end{array}$ \\
\hline Mexico & N/A & - & - \\
\hline Peru & Decree 004-2019-SA & February 22, 2019 & $\begin{array}{l}\text { Mandates national plan, rare disease patient registry, scientific and medical research, } \\
\text { health personnel training, and coordinated care regardless of coverage status or source of } \\
\text { medical care. Also mandates budget impact and other economic evaluation studies for } \\
\text { high-cost rare disease diagnostic tests and medicines to be carried out by a new health } \\
\text { technology evaluation agency called RENETSA. Main public payers are to establish } \\
\text { consultative councils to review rare disease cases to recommend when treatment is } \\
\text { warranted, but final decisions will be made by each payer depending on a budget impact } \\
\text { analysis and funds availability [26]. }\end{array}$ \\
\hline
\end{tabular}

national Advisory Board that could lead to more alignment [19, 27]. In Chile, the Ricarte Soto law folds rare diseases into the broader "high-cost diseases" with no specific regulation of rare diseases other than providing diagnosis and treatment coverage for some. The law does provide some new protections for clinical research subjects [28], but again this is not specific to the rare disease patient community.

In our analysis, the opportunity for regulation is perhaps greatest in Mexico where rare diseases is established in national law and some initiatives exist, but where government coordination and oversight has been minimal. There is a strong case to be made in Mexico for a unified national plan that pulls together the work of the new rare diseases commission of the national health council with access programs established for some patients covered by the Institute for Social Security and Services for State Workers (ISSSTE) and Seguro Popular, for example. Rare disease patient advocacy organizations in Mexico have previously suggested a national plan [29], which has also been requested of the Secretary of Health by the previous Mexican national Senate [30].

\section{Health system incorporation}

A national plan in Mexico might help address the difficult incorporation process for orphan drugs for rare diseases, which at the moment leads to uncertain and inconsistent patient access to needed treatments. Most orphan drugs do not make it through the laborious 
process for national reimbursement in Mexico despite prior approval by the drugs regulatory agency (the Federal Commission for the Protection Against Sanitary Risk, or COFEPRIS). Even when successful, few of these proceed to make it onto individual payer formularies, such as for the Mexican Social Security Institute (IMSS), by far the largest payer in Mexico [31]. Drug purchases without formulary approval can strain the budgets of even the largest healthcare payers making this approach unsustainable over time. A different approach in Mexico could be for the government to consider distinct rules for rare disease medicines in its national formulary process and to make formulary decisions equally binding across all public payers.

Like in Mexico, the incorporation process in Brazil has traditionally been difficult for orphan drugs, though there have been recent improvements as listed in Table 4. A number of rare disease medicines were accepted for SUS inclusion at the end of 2017 with several more in 2018, along with an increase in the number of required PCDTs [32-35]. Key drivers of these recent incorporations in Brazil may have been to secure better prices and limit patient access via lawsuits. Brazil's National Sanitary Surveillance Agency (ANVISA) has also recently rolled out new processes designed to speed review and approval of orphan drugs [36]. If both trends are maintained--speedier approval along with greater possibility for SUS inclusion--access for patients with rare diseases should improve over time.

Of course, health care budgets will need to keep pace with these trends, which is one of the long-term questions for Chile's Ricarte Soto law. Current coverage under the law is outlined in Table 5 . The program covers certain treatments and services for 18 high-cost diseases, 8 of which are rare diseases, and in July 2019 the Ricarte Soto law will begin to cover treatments for an additional 7 rare diseases and conditions [37]. Still, with hundreds of solicitations for program coverage each year, it will be difficult for the Chilean government to meet the public's expectations over time [38]. The budget for Ricarte Soto has doubled since implementation, but up to December 2018 the program had served a total of only about 13,000 patients with approximately 8000 still receiving treatment [39].

Health systems in Colombia, Argentina, and Peru so far lack specific processes for prioritizing access to rare disease treatments. In Peru, the final regulation mandates the health ministry build a list of rare diseases and their respective high-cost treatments, but stops short of describing reimbursement parameters. In Colombia and Argentina, litigation for access has been described as routine $[40,41]$. All three governments are focused on price control, centralized purchasing, and new medicine evaluation agencies to limit budget shock and to prioritize value. Still, most of these initiatives are new and in any case are not specific to medicines for rare diseases.

\section{Care delivery}

Many would consider Peru's final regulation to be a missed opportunity for the government to organize and sanction a network of reference centers for the treatment and management of rare disease patients. After all, previous drafts of the regulation included this idea [42], plus there are a few institutions in Peru that lead efforts in rare disease research, diagnosis, and treatment [43]. The omission is all the more glaring given that the final regulation in Peru mandates more research in rare diseases, as well as more training opportunities for health personnel. Diagnostic and treatment reference centers could be something to advocate for in Peru as the health ministry begins to develop a national plan for rare diseases.

In Argentina the greatest current opportunity is for the government and patient advocates to work together on a mapping of the country's infrastructure with regard to the care and management of rare disease patients. This is one of the few areas in which there is general alignment between Argentina's national law and its implementing regulations. Also, patient advocacy organizations like the Federation of Rare Diseases in Argentina (FADEPOF) have experience in conducting surveys of the rare disease community [44], while the government has implemented some rare disease training for physicians in public hospitals across the country [45]. Data collected from these kinds of efforts could form the basis for the rare disease infrastructure mapping required by law.

Colombia's Health Ministry issued a resolution in 2018 to establish diagnostic and treatment reference centers among existing health care institutions, as well as to sketch how these reference centers should be networked. A detailed manual was made available for any institution seeking reference center status [25]. To date, there has been little news as to whether or how many reference centers are being designated. Still, this effort to better organize the delivery of care to rare disease patients is promising, especially given Colombia's focus on mandated systems for tracking rare diseases and on the specified rights of these patients enshrined in Circular 011 from the Colombian Health Superintendency [46].

In Mexico, ISSSTE and Seguro Popular have adopted programs to allow some patients with rare diseases to access treatments and services $[47,48]$. However, coverage is highly selective and continuously subject to administrative barriers that result in significant access delays. Moreover, if the new Administration has its way, Seguro Popular for the most vulnerable populations 
Table 4 Brazil SUS Incorporations and PCDTs - National Committee for Technology Incorporation (CONITEC) Recommendations 2016-2019

\begin{tabular}{|c|c|c|c|c|}
\hline Year & Treatment & Rare Disease & Decision & Date \\
\hline 2016 [32] & - & - & - & - \\
\hline- & Tobramycin & Cystic Fibrosis & Incorporate & $10 / 27 / 2016$ \\
\hline- & Golimumab & Psoriatic Arthritis & Incorporate & $4 / 12 / 2016$ \\
\hline- & Pancrelipase & Cystic Fibrosis & Exclude & 1/18/2016 \\
\hline 2017 [33] & - & - & - & - \\
\hline- & Idursulfase & MPS ॥ & Incorporate & $12 / 20 / 2017$ \\
\hline- & Somatropin & Turner Syndrome and Hypopituitarism & Incorporate & $11 / 3 / 2017$ \\
\hline- & Laronidase & MPS I & Incorporate & 9/4/2017 \\
\hline- & PCDT & Cystic Fibrosis (Pancreatic Insufficiency) & Approve & 9/4/2017 \\
\hline- & PCDT & Cystic Fibrosis (Pulmonary) & Approve & 9/4/2017 \\
\hline- & Alfataliglicerase & Gaucher Disease & Increase use & $7 / 12 / 2017$ \\
\hline- & PCDT & Psoriatic Arthritis & Approve & $7 / 19 / 2017$ \\
\hline- & PCDT & Gaucher Disease & Approve & $6 / 27 / 2017$ \\
\hline 2018 [34] & - & - & - & - \\
\hline- & Pirfenidone & Idiopathic Pulmonary Fibrosis & Not Incorporate & $12 / 26 / 2018$ \\
\hline- & Nintedanib & Idiopathic Pulmonary Fibrosis & Not Incorporate & $12 / 26 / 2018$ \\
\hline- & Zoledronic Acid & Paget's Disease & Incorporate & $12 / 21 / 2018$ \\
\hline- & Galsulfase & MPS VI & Incorporate & $12 / 20 / 2018$ \\
\hline- & Elosulfase Alfa & MPS IVa & Incorporate & $12 / 20 / 2018$ \\
\hline- & Sapropterin & Phenylketonuria & Incorporate & $12 / 17 / 2018$ \\
\hline- & Eculizumab & Paroxistic Nocturnal Hemoglobinuria & Incorporate & $12 / 17 / 2018$ \\
\hline- & Agalsidase (Alfa and Beta) & Fabry's Disease & Not Incorporate & $12 / 17 / 2018$ \\
\hline- & Eltrombopag Olamine & Idiopathic Thrombocytopenic Purpura & Incorporate & $12 / 12 / 2018$ \\
\hline- & Romiplostim & Idiopathic Thrombocytopenic Purpura & Not Incorporate & $12 / 12 / 2018$ \\
\hline- & PCDT & Autoimmne Hemolytic Anemia & Approve & $12 / 10 / 2018$ \\
\hline- & PCDT & Psoriatic Arthritis & Approve & $11 / 5 / 2018$ \\
\hline- & PCDT & Familial Amyloid Polyneuropathy & Approve & 10/10/2018 \\
\hline- & PCDT & MPS ॥ & Approve & $5 / 25 / 2018$ \\
\hline- & PCDT & Turner Syndrome & Approve & $5 / 24 / 2018$ \\
\hline- & PCDT & Autoimmune Hepatitis & Approve & $5 / 24 / 2018$ \\
\hline- & PCDT & Biotinidase Deficiency & Approve & $5 / 24 / 2018$ \\
\hline- & PCDT & MPS I & Approve & $4 / 18 / 2018$ \\
\hline- & PCDT & Wilson Disease & Approve & $4 / 9 / 2018$ \\
\hline- & PCDT & Sickle Cell Disease & Approve & $2 / 22 / 2018$ \\
\hline- & Certolizumab & Psoriatic Arthritis & Not Incorporate & $1 / 25 / 2018$ \\
\hline- & Ustekinumab & Psoriatic Arthritis & Not Incorporate & $1 / 25 / 2018$ \\
\hline- & Tafamidis & Familial Amyloid Polyneuropathy & Incorporate & $1 / 18 / 2018$ \\
\hline 2019 (Up to 4/1/19) [35] & - & - & - & - \\
\hline- & Eftrenonacog Alfa & Hemophilia B & Not Incorporate & 2/22/2019 \\
\hline- & Efmoroctocog Alfa & Hemophilia A & Not Incorporate & 2/22/2019 \\
\hline- & Secukinumab & Psoriatic Arthritis & Incorporate & $1 / 21 / 2019$ \\
\hline- & PCDT & Acromegaly & Approve & $1 / 14 / 2019$ \\
\hline
\end{tabular}


Table 5 Ricarte Soto Law - Covered Rare Diseases [37]

\begin{tabular}{cll}
\hline & Disease/Condition & Treatment \\
\hline Current Coverage & & Laronidase \\
2 & Mucopolysaccharidosis I & Idursulfase \\
3 & Mucopolysaccharidosis II & Galsulfase \\
4 & Mucopolysaccharidosis VI & Nitisinone \\
5 & Tyrosinemia & Taliglucerase or Imiglucerase \\
6 & Gaucher Disease & Agalsidase Alfa or Beta \\
7 & Fabry Disease & Ambrisentan, Bosentan, or Iloprost \\
8 & Pulmonary Arterial Hypertension (Group 1) & C1 Esterase Inhibitor \\
Additions for Coverage beginning July 1, 2019 & Treatment Pack \\
9 & Epidermolysis Bullosa (dystrophic or junctional) & Technical Assistance and Devices \\
10 & Amyotrophic Lateral Sclerosis (moderate to severe) & Imatinib or Sunitinib \\
11 & Gastrointenstinal Stromal Tumor (GIST) & Golimumab, Etanercept, Adalimumab, \\
12 & Psoriatic Arthritis (moderate to severe, refractory) & or Secukinumab \\
13 & Ulcerative Colitis (moderate to severe, refractory) & Golimumab or Adalimumab for \\
15 & Myelofibrosis (primary and secondary to other myeloproliferative neoplasms) & moderate; Infliximab for severe
\end{tabular}

could be absorbed by IMSS, creating new uncertainty for rare disease patients without any type of health insurance coverage [49]. Given Mexico's concentration of medical specialty expertise and services in major urban areas of the north, west, and center of the country, there is opportunity in building strong regional networks of diagnosis and treatment reference centers for rare diseases. In fact, mapping the country's existing medical infrastructure for rare diseases should be a future policy goal in Mexico.

Ordinance 199 in Brazil has a large focus on care delivery via rare disease reference centers. Throughout 2016, seven centers received full authorization from the Ministry of Health, while another ten hospitals had been accredited to provide services for rare disease patients but were awaiting full authorization. Nevertheless, the relative scarcity of rare disease PCDTs means the services provided by these reference centers are limited. In fact, most fully authorized centers in Brazil focus on birth defects, inborn errors of metabolism, and/or intellectual disabilities. In addition, most of the reference centers able to provide rare disease services of any kind are still concentrated in the major urban centers of Sao Paulo and Rio de Janeiro [12]. It remains to be seen if recent rare disease drug incorporations into SUS leads to a greater range of rare diseases being attended to in Brazilian reference centers.

In Chile, the process established by the Ricarte Soto law requires an officially sanctioned clinical treatment guideline prior to consideration of a disease and its medicine for coverage [37]. Perhaps the assumption was that the new law would incentivize the production of such treatment guidelines, and in doing so raise quality standards of care across the board. But it appears this has not been a priority for the Health Ministry as it implements the law. The focus has been on diseases and conditions where care standards already exist, instead of on new treatment guidelines, which may put lesserknown rare diseases at a relative disadvantage for coverage within the high-cost disease category [50].

\section{Patient engagement}

Patient engagement comes in many forms and at different levels. Some of the major rare disease patient organizations in the six countries are listed in Table 6. A government's willingness to engage with patient advocates can be an important measure of a country's sustainable policy framework in rare diseases. For example, laws can establish a national recognition day for rare diseases to provide non-governmental groups an important platform for public awareness. Similarly, regulations can mandate that patient advocates be included in rare disease policy, governance and oversight entities.

In Brazil, rare disease Ordinance 199 includes no provisions for regular engagement with patient advocates in spite of mandating increased public awareness about rare diseases. Rare disease patient advocates and their 
Table 6 Rare Disease Patient Advocacy Organizations in Six Latin American Countries

\begin{tabular}{lll}
\hline $\begin{array}{l}\text { Argentina } \\
\text { Brazil }\end{array}$ & Federación Argentina de Enfermedades Poco Frecuentes (FADEPOF) & http://fadepof.org.ar/ \\
Chile & Instituto Vidas Raras & http://www.vidasraras.org.br/site/ \\
Chile & Fundación de Enfermedades Lisosomales Chile (FELCH) & http://www.fundacionfelch.cl/ \\
Colombia & Federación Chilena de Enfermedades Raras (FECHER) & https://twitter.com/fecher_cl \\
Colombia & Federación Colombiana de Enfermedades Raras (FECOER) & http://www.fecoer.org/ \\
Mexico & Observatorio Interinstitucional de Enfermedades Huerfanas (ENHU) & https://twitter.com/EHuerfanasCo \\
Mexico & Organización Mexicana de Enfermedades Raras (OMER) & http://omer.org.mx/ \\
Peru & Federación Mexicana de Enfermedades Raras (FEMEXER) & http://www.femexer.org/ \\
Peru & Coalición Peruana de Enfermedades Poco Frecuentes (COPEPOFRE) & http://www.esperantra.org/index. \\
php/copepofre
\end{tabular}

organizations are involved in Brazilian policy efforts in terms of pending legislative proposals [51]. Advocates also take part voluntarily in the SUS incorporation process when medicines that serve their respective communities are up for consideration [52]. Still, the opportunity is great for the government of Brazil to more officially recognize the expertise and engage more formally with patient advocates.

There is also opportunity in Peru for the health ministry to capitalize on growing expertise from the patient advocacy community. There is a Peruvian Federation of Rare Diseases (FEPER) made up of 17 different rare disease patient-based associations [53]. In addition, 23 rare disease patient-based associations in 2016 formed the Peruvian Coalition for Rare Diseases (COPEPOFRE) to collaborate on rare disease and orphan drug policy advocacy [54]. In 2012, shortly after Peru passed its national law on rare diseases, an annual day of recognition was established and advocates have been able to use that opportunity each year to raise public awareness [55]. Unfortunately, the final regulation implementing Peru's national rare diseases law avoids both patient engagement and public awareness as priorities even though earlier drafts had included these as priorities.

In Mexico, patient advocacy organizations were instrumental in establishing the program in rare diseases at ISSSTE [56], but were not included in any of the official processes when Mexico's General Health Council established its National Rare Diseases Commission in 2017 [57]. Several organizations have been effective in the larger urban centers of the country and some of them work with members of the national Congress to raise awareness and seek policy solutions. Nevertheless, questions have arisen as to whether the current Administration is open to input from civil society, in general, which could have an impact on rare disease patient advocacy in Mexico [58].

It is noteworthy for the region that in Chile patient advocates participate officially in the different processes of the Ricarte Soto program as high-cost diseases and medicines are considered for coverage. The law is explicit in that patient and public input be considered [38]. Nevertheless, participation in official decision making is limited to only a few advocates at any one time. Also, strict rules on conflict-of-interest govern selection, which can unnecessarily preclude direct participation by patient advocates who have the most experience in the field. This selection bias can be especially acute in the field of rare diseases where the number of advocates for each disease is fewer than for more common high-cost health conditions, further compounding the relative disadvantage of rare diseases within the Ricarte Soto program. It has also been reported that the Ricarte Soto law has served to divide the rare disease patient community in Chile [59].

In Colombia, rare disease patient advocates were instrumental in the adoption of Law 1392 and the strong focus on ensuring rare disease patients have certain inalienable rights and protections within the health system [60]. A voluntary working group on rare diseases within the Ministry of Health has been meeting regularly since 2012 and includes patient advocacy representatives [61]. At the municipal level, in June 2014 Bogota's mayor issued Resolution 1147 establishing a technical coordinating committee that meets regularly to design and implement strategies to address the needs of patients with rare diseases. The resolution included a mandate to include on the committee a representative from the Colombian Federation of Rare Diseases (FECOER), which set an important precedent for patient advocates to work closely with city government officials and physicians on rare disease policy [62].

Argentina's rare disease law includes a mandate for a multidisciplinary advisory board to help the government develop and promote initiatives. Only in February 2019 did this advisory board become officially constituted with rare disease patient advocates to be represented by FADEPOF, among others [63]. While an important step forward, the Federation has in fact articulated several 
initiatives over the years for the Argentine government to implement, including both the basis for an official disease registry and a detailed national plan for rare diseases [64]. A rare diseases registry is currently being piloted by the government as part of Argentina's National Health Information System (SIISA), which includes other data registries [65]. With the work of the advisory board soon underway, it remains to be seen if the authorities will now be more open to the expertise and resources on offer by civil society [66].

\section{Conclusions}

This paper summarizes rare disease public policy and the current context for implementation in Argentina, Brazil, Chile, Colombia, Mexico, and Peru. Five policy dimensions were chosen to facilitate analysis among the six countries: national laws, national regulations, health system incorporation of rare disease treatments, care delivery, and patient engagement. Based on these dimensions, several opportunities were identified for strengthening rare disease policies. Here we summarize these opportunities for each country.

In Argentina, almost eight years have passed since passage of the rare diseases national law and four years since implementing regulations were adopted. Regulatory ambiguity is likely responsible for at least some of the lack of concrete action on rare diseases and greater clarity via Congressional action or by the Administration is an important opportunity. Another important opportunity is a mapping of the country's infrastructure with regard to the care and management of rare disease patients. Both patient advocates and the government have relevant expertise in this area.

In Brazil, there is opportunity with the many legislative proposals in Congress to pass a national law that serves to fill gaps and modernize the rare diseases Ordinance 199 from 2014. Much progress has recently been made by both ANVISA and CONITEC in terms of new regulatory pathways for orphan drug review, PCDTs, and SUS incorporation recommendations. There is opportunity in ensuring these decisions translate quickly to the benefit of rare disease patients in SUS specialized care units and authorized reference centers where multidisciplinary teams of health professionals manage care.

In Chile, it is increasingly apparent that while the Ricarte Soto Law has benefitted some rare disease patients with coverage and access to treatment, the program is insufficient in terms of unmet medical need and perhaps unsustainable over time. There is significant opportunity in Chile to pursue laws and regulations specific to rare diseases, which at the very least would facilitate productive interactions among a highly fragmented rare disease patient advocacy community.
Colombia's rare disease law is the oldest of the six countries-adopted in 2010-and has an explicit emphasis on protecting the rights of patients with rare diseases. Rare disease advocates have been able to exercise those rights whenever additional health care reforms are proposed. Nevertheless, Colombia's implementing regulations have focused mostly on disease and patient identification, with the recent regulation to establish authorized rare disease reference centers a step forward. The opportunity in Colombia is for the government to meaningfully address the mostly negative experience of rare disease patients in accessing quality care.

Mexico benefits from a concentration of medical specialty expertise and services in several large urban areas of the country. There is opportunity for the government to build capable regional networks of diagnosis and treatment reference centers for rare diseases. As an initial step, a map of Mexico's existing medical infrastructure for rare diseases should be a future policy goal. There is also significant opportunity for a different approach with distinct rules for rare disease medicines in its national formulary process. The rare diseases commission of Mexico's National Health Council should be encouraged to work with patient advocates to link their initial efforts at building a rare disease registry to other policy processes governing access to rare disease medicines and services.

The rare diseases law and final regulation in Peru mandates the development of an action plan, which can be an important means of building consensus and benchmarking progress on the country's policy objectives. When updated regularly, national plans can keep stakeholders focused on respective priorities and governments can be held more accountable for results. The opportunity in Peru is for the government and advocates to work together to ensure key elements omitted from the final regulation-such as diagnostic and treatment reference centers or patient engagement-are reinserted as priorities as the health ministry begins to develop a national plan for rare diseases.

Finally, we note that recent landmark Presidential elections in Brazil, Mexico, and Colombia, as well as one upcoming in Argentina are likely to have an impact on health care plans and priorities, and by extension, government programming in rare diseases. It is imperative that rare disease leaders in each country continue their work to educate newly elected or appointed stakeholders on the progress achieved as well as pending opportunities to build and advance policy frameworks on behalf of rare disease patients. Readers are encouraged to review the Asia-Pacific Economic Cooperation's (APEC) Rare Disease Network Action Plan launched in November 2018 to provide a framework for continued rare disease policy action by each of its 21-member economies [67]. In addition, continued in-depth research and analysis will help our 
respective stakeholder communities across Latin America identify salient opportunities, build consensus, and make significant improvements moving forward.

\section{Study limitations}

We chose five dimensions to analyze rare disease policy in six Latin American countries based on patient advocate views supplemented by online research. Additional national or local laws such as rules on newborn screening, human rights, and disabilities were not considered in this analysis but can have significant impact on the welfare of the community of rare disease patients. Another study limitation is heavy reliance on patient advocate perspectives, which can bias the findings in this paper especially as these views were collected during the course of several face-to-face patient advocate meetings and telephone discussions in 2016, 2017, and 2018. Further structured research to validate patient advocate views and that include the experience and perspectives of additional stakeholder groups would help elucidate rare disease policy implementation across Latin America. Finally, we did not employ any technical platform to conduct the desktop research, including for the literature search. This introduces certain subjective bias into the findings as we may have missed or overlooked publications or other key resources relevant to the topics discussed in this paper.

\section{Abbreviations \\ ANVISA: Brazil's National Sanitary Surveillance Agency; APEC: Asia-Pacific Economic Cooperation; COFEPRIS: Mexico's Federal Commission for the Protection Against Sanitary Risk; CONITEC: Brazil's National Committee for Technology Incorporation; COPEPOFRE: Peruvian Coalition for Rare Diseases, FADEPOF: Federation of Rare Diseases in Argentina; FECOER: Colombian Federation of Rare Diseases; FEPER: Peruvian Federation of Rare Diseases; IMSS: Mexican Social Security Institute; ISSSTE: Mexico's Institute for Social Security and Services for State Workers; PCDT: Brazil's Clinical and Therapeutic Protocols; RENETSA: Peru's National Network for Health Technology Evaluation; SISPRO: Colombia's Integrated Information System for Social Protection; SUS: Brazil's Unified Health System \\ Acknowledgements \\ Country-specific input collected from Ines Castellanos and Luciana Escati from FADEPOF (Argentina), Regina Prospero from IVR (Brazil), Myriam Estivil from FELCH (Chile), Eliana Sepulveda from FECOER (Colombia), Martha Gualtero from ENHU (Colombia), Jesus Navarro from OMER (Mexico), and Karla Ruiz de Castilla from COPEPOFRE (Peru).}

\section{Authors' contributions}

Conceived and designed the review: MM, ER, SS. Compiled and analyzed the reviewed material: MM, ER, SS. Wrote the paper: MM. All authors read and approved the final manuscript.

\section{Funding}

This project was funded by Pfizer Inc.

\section{Availability of data and materials}

The datasets used and/or analyzed during the current study available from. the corresponding author on reasonable request.

Ethics approval and consent to participate Not applicable.
Consent for publication

Not applicable.

\section{Competing interests}

$M M, E R$, and SS receive project funding from Pfizer, Inc.

\section{Author details}

${ }^{1}$ Emoluva Partners, LLC, 10142 SW 79th Avenue, Miami, FL 33156, USA. ${ }^{2}$ Latin America Patients Academy, Miami, FL, USA. ${ }^{3}$ Knight \& Pawn, Miami, FL, USA.

Received: 15 August 2019 Accepted: 21 January 2020

Published online: 27 February 2020

\section{References}

1. Annemans $L$, Aymé S, Le Cam Y, et al. Recommendations from the European working Group for Value Assessment and Funding Processes in rare diseases (ORPH-VAL). Orphanet J Rare Dis. 2017; https://doi.org/10.1186/ s13023-017-0601-9.

2. Gammie T, Lu CY, Babar ZU. Access to orphan drugs: a comprehensive review of legislations, regulations and policies in 35 countries. PLoS One. 2015; https://doi.org/10.1371/.pone.0140002

3. Dharssi S, Wong-Rieger D, Harold M, Terry S. Review of 11 national policies for rare diseases in the context of key patient needs. Orphanet J Rare Dis. 2017; https://doi.org/10.1186/s13023-017-0618-0.

4. Chavez A, Denis M. Rare diseases in Latin America: challenges and opportunities for the equitable attention and proposal of patients organizations. In: News Across Latin America. ISPOR; 2017. http://press.ispor. org/LatinAmerica/2017/09/rare-diseases-in-latin-america-challenges-andopportunities-for-the-equitable-attention-and-proposal-of-patientsorganizations/. Accessed 12 Feb 2019.

5. Khosla N, Valdez R. A compilation of national plans, policies and government actions for rare diseases in 23 countries. Intractable Rare Dis Res. 2018; https://doi.org/10.5582/irdr.2018.01085.

6. Ministerio de Salud y Protección Social. Ley 1392. 2010. https://www. minsalud.gov.co/sites/rid/Lists/BibliotecaDigital/RIDE/DE/DIJ/ley-1392-de2010.pdf. Accessed 27 Jan 2020.

7. Congreso de la Republica. Normas Legales: Ley 29698. 2011. https:// busquedas.elperuano.pe/normaslegales/ley-que-declara-de-interes-nacionaly-preferente-atencion-el-ley-n-29698-649311-1/. Accessed 27 Jan 2020

8. Orden Jurídico México. Ley General de Salud. No date. http://www. ordenjuridico.gob.mx/Documentos/Federal/html/wo11037.html. Accessed 27 Jan 2020.

9. Atlas Federal de Legislación Sanitaria de la Republica de Argentina. Ley 26689. No date. http:/test.e-legis-ar.msal.gov.ar/leisref/public/showAct. php?id=18173\#. Accessed 27 Jan 2020.

10. Ministerio de Saúde. Portaria № 199, de 30 de Janeiro de 2014. No date. http://bvsms.saude.gov.br/bvs/saudelegis/gm/2014/prt0199_30_01_2014. html. Accessed 27 Jan 2020.

11. Biblioteca del Congreso Nacional de Chile. Ley 20850. No date. https:// www.leychile.cl/Navegar?idNorma=1078148. Accessed 27 Jan 2020.

12. INTERFARMA. Rare Diseases: The Urgency of Access to Health. INTERFARMA. 2018. https://www.interfarma.org.br/public/files/biblioteca/rare-diseases-theurgency-of-access-to-health-interfarma.pdf. Accessed 12 Feb 2019.

13. Bastías $\mathrm{G}$, et al. Policy brief: financing options for the treatment of rare diseases in Chile. In: EVIP-NET Chile: In; 2011. https:/www.who.int/ evidence/resources/policy_briefs/PBChileFinancing.pdf . Accessed 13 Feb 2019

14. Secretaría de Gobierno de Salud. Enfermedades Pocos Frecuentes. In: Atlas Federal de Legislación Sanitaria de la Republica de Argentina. No date. http://www.legisalud.gov.ar/atlas/categorias/poco_frecuentes.html. Accessed 13 Feb 2019.

15. Alcaldía de Bogotá DC. Resolución Numero 1147: Mesa Técnica Distrital de las Enfermedades Huerfanas. 2014. http://www.fecoer.org/download/SDSresolucion-1147\%202014.pdf. Accessed 14 Feb 2019.

16. Consejo Municipal de Cali. Acuerdo 0403: Mesa Técnica Municipal de Enfermedades Huerfanas. 2016. http://www.fecoer.org/acuerdo-403-dediciembre-de-2016-establece-mesa-municipal-de-enfermedades-raras-encali/. Accessed 14 Feb 2019.

17. Atlas Federal de Legislación Sanitaria de la Republica de Argentina. Resolución 2329/2014. No date. http://test.e-legis-ar.msal.gov.ar/leisref/ 
public/showAct.php?id=24070\&word=enfermedades\%20poco\% 20frecuentes. Accessed 27 Jan 2020.

18. Atlas Federal de Legislación Sanitaria de la Republica de Argentina. Decreto 794/2015. No date. http://test.e-legis-ar.msal.gov.ar/leisref/public/showAct. php?id=24681\&word=enfermedades\%20poco\%20frecuentes. Accessed 27 Jan 2020.

19. Boletín Oficial de la Republica de Argentina. Legislacion y Avisos Oficiales: Resolución 271/2019. No date. https://www.boletinoficial.gob.ar/ detalleAviso/primera/201559/20190213. Accessed 27 Jan 2020.

20. Ministerio de Salud y Protección Social. Decreto 1954. 2012. http://www. fecoer.org/download/DECRETO\%201954\%20DEL\%2019\%20DE\% 20SEPTIEMBRE\%20DE\%202012.pdf. Accessed 27 Jan 2020.

21. Ministerio de Salud y Protección Social. Resolución 430. 2013. http://www. fecoer.org/download/Resoluci\%C3\%B3n\%200430\%20de\%202013.pdf. Accessed 27 Jan 2020.

22. Ministerio de Salud y Protección Social. Resolución 3681. 2013. http://www. fecoer.org/download/Res_3681_de_2013.pdf. Accessed 27 Jan 2020.

23. Ministerio de Salud y Protección Social. Resolución 123. 2015. https://www. minsalud.gov.co/sites/rid/Lists/BibliotecaDigital/RIDE/DE/DIJ/resolucion0123-de-2015.pdf. Accessed 27 Jan 2020.

24. Ministerio de Salud y Protección Social. Resolución 2048. 2015. http://www. fecoer.org/download/Resoluci\%C3\%B3n\%202048\%20de\%202015\%20Lista\% 20ER\%20.pdf. Accessed 27 Jan 2020

25. Ministerio de Salud y Protección Social. Resolución Numero 651: Condiciones de Habilitación de los Centros de Referencia ... . para la Atención Integral de las Enfermedades Huérfanas. 2018. https://www. minsalud.gov.co/sites/rid/Lists/BibliotecaDigital/RIDE/DE/DIJ/resolucion-651de-2018.pdf. Accessed 14 Feb 2019.

26. El Peruano. Decreto Supremo No. 004-2019-SA: Reglamento de la Ley Nº 29698, Ley que declara de Interés Nacional y Preferente Atención el Tratamiento de personas que padecen Enfermedades Raras o Huérfanas. 2019. https://busquedas.elperuano.pe/normaslegales/reglamento-de-la-leyn-29698-ley-que-declara-de-interes-na-decreto-supremo-n-004-2019-sa1743601-5/. Accessed 14 Feb 2019.

27. FADEPOF. Se ha Creado el Consejo Consultivo Honorario de Enfermedades Poco Frecuentes. In: Noticias; 2019. http://fadepof.org.ar/noticias/290. Accessed 14 Feb 2019.

28. Kottow Lang MH. Conceptual clarifications regarding Chilean act 20850 on public funding of high-cost diseases. Medwave. 2016; https://doi.org/10. 5867/medwave.2016.03.6436.

29. FEMEXER. PlanER: Plan Nacional de Enfermedades Raras. No date. http:// www.femexer.org/11245/plan-nacional-de-enfermedades-raras/. Accessed 13 Feb 2019.

30. Gaceta del Senado. Punto de Acuerdo de la Comisión de Salud: Exhorta ... la creación de un plan nacional de enfermedades raras. 2017. http://www. senado.gob.mx/64/gaceta_del_senado/documento/69616. Accessed 15 Feb 2019.

31. Geneva Network. Biopharmaceutical innovation in Mexico: at the crossroads No date https://geneva-network.com/article/biopharmaceutical-innovationmexico-crossroads/. Accessed 12 Feb 2019.

32. CONITEC. Recommendations for Evaluated Technologies: 2016. Updated 2020. http://conitec.gov.br/recomendacoes-sobre-as-tecnologias-avaliadas2016.

33. CONITEC. Recommendations for Evaluated Technologies: 2017. Updated 2019. http://conitec.gov.br/recomendacoes-sobre-as-tecnologias-avaliadas2017.

34. CONITEC. Recommendations for Evaluated Technologies: 2018. Updated 2019. http://conitec.gov.br/recomendacoes-sobre-as-tecnologias-avaliadas2018 . .

35. CONITEC. Recommendations for Evaluated Technologies: 2019. Updated 2020. http://conitec.gov.br/recomendacoes-sobre-as-tecnologias-avaliadas2019.

36. Barbosa J. Regulatory Advances in Drug Regulation Accelerated Pathways of Approval. In: ANVISA Presentation at DIA 2018 Annual Meeting, Session \#264; 2018. http://portal.anvisa.gov.br/documents/219201/219401/ANVISA+ JB+DIA+2018+Annual+Meeting+INGLES/4bea5429-ef3c-4b6a-9bb3324896228c9e. Accessed 18 Feb 2019.

37. Ministerio de Salud de Chile. Ricarte Soto Ley 20.850. 2019. https://www. minsal.cl/leyricarte/. Accessed 13 Feb 2019.

38. Inter-American Development Bank. La Cobertura de las Intervenciones de Alto Costo en Chile: Una Vision Critica Sobre la Ley Ricarte Soto. 2017. https://publications.iadb.org/es/publicacion/13999/breve-17-la-cobertura-delas-intervenciones-de-alto-costo-en-chile-una-vision. Accessed 13 Feb 2019.

39. VivePais. Ley Ricarte Soto: 9 Enfermedades nuevas tendrán cobertura este año. 2019. http://www.vivepais.cl/2019/02/16/ley-ricarte-soto-9enfermedades-nuevas-tendran-cobertura-este-ano/. Accessed 13 Feb 2019

40. RCNRadio. Se dispara número de tutelas dentro del sistema de salud en Colombia. 2018. https://www.rcnradio.com/salud/se-dispara-el-numero-lastutelas-dentro-del-sistema-de-salud-en-colombia. Accessed 12 Feb 2019.

41. Gotlieb V, Yavich N, Báscolo E. Litigation and the right to health in Argentina. Cad Saúde Pública. 2016; https://doi.org/10.1590/0102$311 \times 00121114$.

42. Ministerio de Salud de Peru. Resolución Ministerial No. 154-2018/MINSA. Proyecto de Reglamento de la Ley N²9698, Ley que declara de Interés Nacional y Preferente Atención el Tratamiento de Personas que padecen Enfermedades Raras o Huérfanas. 2018. https://www.gob.pe/institucion/ minsa/normas-legales/187573-154-2018-minsa. Accessed 14 Feb 2019.

43. Lizaraso Caparó F, Fujita R. Rare or orphan diseases: more orphan than rare in Peru. Horizonte Médico. 2018; https://doi.org/10.24265/horizmed.

44. Escati G, Escati L. Informe sobre "Dimensionamiento de las EPOF en Argentina" elaborado por FADEPOF. 2017. http://fadepof.org.ar/downloads/ Informe\%20-\%20Dimensionamiento\%20de\%20EPOF\%20en\%20Argentina\% 20-\%20FADEPOF.pdf. Accessed 14 Feb 2019

45. Ministerio de Salud y Desarrollo Social de Argentina. Curso Interactivo de Enfermedades Poco Frecuentes. 2018. http://www.msal.gov.ar/congenitas/ curso-interactivo-de-enfermedades-poco-frecuentes/. Accessed 14 Feb 2019

46. SuperSalud Colombia. Circular Externa 011: Instrucciones para la atención de enfermedades huérfanas. 2016. https://docs.supersalud.gov.co/ PortalWeb/Juridica/CircularesExterna/circular\%20externa\%20011\%20de\% 202016.pdf. Accessed 15 Feb 2019.

47. ISSSTE. Prensa: Las enfermedades raras, un reto para el sector salud. 2013 https://www.gob.mx/issste/prensa/las-enfermedades-raras-un-reto-para-elsector-salud. Accessed 13 Feb 2019

48. Lozano R, Garrido F. Catastrophic Health Expenditure Fund: Mexico case study. WHO/HIS/HGF Case Study. 2015. https://www.who.int/health_ financing/documents/Efficiency_health_systems_Mexico/en/. Accessed 13 Feb 2019.

49. El Economista. IMSS Absorberá al Seguro Popular con IMSS-Bienestar. 2018. https://www.eleconomista.com.mx/empresas/IMSS-absorbera-al-SeguroPopular-con-IMSS-Bienestar-20181204-0005.html. Accessed 13 Feb 2019.

50. Microjuris. Enfermedades Raras y Ley Ricarte Soto: legisladores piden norma especial que les garantice cobertura. 2017. https:/aldiachile.microjuris.com/ 2017/03/27/enfermedades-raras-y-ley-ricarte-soto-legisladores-piden-normaespecial-que-les-garantice-cobertura/. Accessed 14 Feb 2019.

51. Instituto Vidas Raras. Câmara recebe $4^{a}$ Edição do evento \#TODOSpelosRAROS. No date. http://www.vidasraras.org.br/site/vidas-raras/ noticias/515-camara-recebe-4-edicao-do-evento-todospelosraros. Accessed 15 Feb 2019.

52. Instituto Vidas Raras. Consulta Pública - Proposta Incorporação Medicamentos para MPS IV e MPS VI. http://www.vidasraras.org.br/site/ vidas-raras/noticias/521-consulta-publica-proposta-incorporacaomedicamentos-para-mps-iv-e-mps-vi. Accessed 15 Feb 2019.

53. FEPER. Website. 2019. http://feperperu.blogspot.com/. Accessed 14 Feb 2019

54. COPEPOFRE. Website. No date. http://www.esperantra.org/index.php/ copepofre. Accessed 14 Feb 2019.

55. El Peruano. Resolucion Ministerial No. 579-2011/MINSA: Día Nacional de las Enfermedades Raras o Huérfanas. 2011. https://busquedas.elperuano.pe/ download/url/declaran-el-ultimo-dia-del-mes-de-febrero-de-cada-ano-comoe-resolucion-ministerial-n-579-2011minsa-669821-5. Accessed 14 Feb 2019.

56. MVT Agencia de Noticias. Dispone ISSSTE de red de servicios para atención de enfermedades huérfanas. 2015. http://mvt.com.mx/dispone-issste-de-redde-servicios-para-atencion-de-enfermedades-huerfanas/. Accessed 13 Feb 2019.

57. Diario Oficial de la Federación. Reglamento Interior de la Comisión para el Análisis, Evaluación, Registro y Seguimiento de las Enfermedades Raras. 2017. http://www.dof.gob.mx/nota_detalle.php?codigo $=5477535 \& f e c h a=24 /$ 03/2017. Accessed 13 Feb 2019.

58. Politico MX. AMLO: no más dinero para OSC y estancias, aunque haya plantones. 2019. https://politico.mx/minuta-politica/minuta-politicagobierno-federal/agenda-amlo-para-jueves-7-de-febrero-visita-igualaguerrero/. Accessed 13 Feb 2019 
59. Enfermedades Raras Chile. Si Fuéramos Unidos, el Estado Cubriría estas Enfermedades. No date. http://enfermedadesraraschile.com/index.php/ felch/. Accessed 15 Feb 2019.

60. Chavez A. Enfermedades Raras en Colombia: brecha entre regulación y acceso efectivo a la Salud. In: Monitor Estratégico - Revista de la Superintendencia Nacional de Salud; 2018. https://www.academia.edu/ 35940260/Enfermedades_Raras_en_Colombia_brecha_entre_regulación_y_ acceso_efectivo_a_la_Salud.pdf. Accessed 14 Feb 2019.

61. FECOER. Mesa de Enfermedades Raras del MINSALUD Colombiano: Avances. 2015. http://www.fecoer.org/avances-de-la-mesa-de-enfermedaes-raras-delminsalud/. Accessed 14 Feb 2019.

62. Alcaldía Mayor de Bogotá. Resolución No. 1147: Se Crea la Mesa Técnica Distrital de las Enfermedades Huérfanas. 2014. http://www.fecoer.org/ download/SDS-resolucion-1147\%202014.pdf. Accessed 14 Feb 2019.

63. FADEPOF. Noticias: Se ha Creado el Consejo Consultivo Honorario de Enfermedades Poco Frecuentes. 2019. http://fadepof.org.ar/noticias/290. Accessed 12 Feb 2019.

64. FADEPOF. Informe: Las Enfermedades Poco Frecuentes en Argentina. 2018 http://fadepof.org.ar/downloads/Informe_EPOF_ARG_FADEPOF_2018_final. pdf. Accessed 12 Feb 2019.

65. Sistema Integrado de Información Sanitaria Argentino, Ministerio de Salud. Website. 2020. https://sisa.msal.gov.ar/sisa/\#sisa. Accessed 9 Jan 2020.

66. FADEPOF. A Poco de Cumplirse "100 días para un Compromiso" Tendremos Plan? http://fadepof.org.ar/noticias/292. Accessed 28 Feb 2019.

67. APEC. APEC Rare Disease Action Plan Sets Precedent to Integrate Rare Disease Care by 2025. No date. https://www.apec.org/rarediseases/News/ APEC-Rare-Disease-Action-Plan-Sets-Precedent-to-Integrate-Rare-DiseaseCare-by-2025. Accessed 15 Mar 2019.

\section{Publisher's Note}

Springer Nature remains neutral with regard to jurisdictional claims in published maps and institutional affiliations.

Ready to submit your research? Choose BMC and benefit from:

- fast, convenient online submission

- thorough peer review by experienced researchers in your field

- rapid publication on acceptance

- support for research data, including large and complex data types

- gold Open Access which fosters wider collaboration and increased citations

- maximum visibility for your research: over $100 \mathrm{M}$ website views per year

At $\mathrm{BMC}$, research is always in progress.

Learn more biomedcentral.com/submissions 